\title{
Crossings: Introduction
}

\section{Françoise Kral}

\section{(2) OpenEdition}

1 Journals

Electronic version

URL: https://journals.openedition.org/ces/5102

DOI: $10.4000 /$ ces. 5102

ISSN: 2534-6695

\section{Publisher}

SEPC (Société d'études des pays du Commonwealth)

\section{Printed version}

Date of publication: 1 September 2014

Number of pages: 5-9

ISSN: 2270-0633

\section{Electronic reference}

Françoise Kral, "Crossings: Introduction", Commonwealth Essays and Studies [Online], 37.1 | 2014

Online since 14 April 2021, connection on 18 July 2021. URL: http://journals.openedition.org/ces/5102 ; DOI: https://doi.org/10.4000/ces.5102

\section{(c) (1) 9}

Commonwealth Essays and Studies is licensed under a Licence Creative Commons Attribution - Pas d'Utilisation Commerciale - Pas de Modification 4.0 International. 


\section{Introduction}

Although common currency in the field of postcolonial studies for some time now, the concept of "crossings" continues to be an insightful entry point into a domain which, since its birth, has been at the crossroads of several disciplines in the humanities. The term seems to have natural moorings both in the history of postcolonial studies, as exemplified notably by the triangular geography of the slave trade, the commercial trajectories of overseas trade and the redeployment of these trajectories in the larger framework of colonialism. More recently, crossings have also become a dominant theme in diasporic studies where the term evokes the diasporic trajectories of migrants away from the home country as well as the return journeys to the motherland narrated in contemporary "homecoming narratives."

This thematic grounding of postcolonial texts into a larger framework characterized by crossings, either imposed or willingly undertaken, temporary or permanent, and which triggered other types of crossings, linguistic, cultural and sometimes religious, has gone hand in hand with the shaping of an aesthetics which has largely drawn on other types of crossings. The dialogue between the colonial power, which had the upper hand not only economically and politically, but also culturally and linguistically, has called for a response which has made good use of intertextuality and generic rewritings to subversive ends, thereby tying the politics of the postcolonial text to an aesthetics of generic and linguistic crossings which has sought to interrogate and shake the foundations of the grand narratives of colonialism and imperialism, and has by and large proved successful in this regard.

More recently thematic and formal crossings have tended to crystallize in less openly politicized debates and less forceful affirmations of identity as younger generations of writers have come centre stage and have made other forms of crossing possible, visible and audible, and with them new ideas of hybridity, double-belonging and wilful mongrelisations. The hybridization of the cultures involved in such crossings has been reflected in the increasingly complex and diverse mixing of narrative voices and literary traditions within the narratives, creating a thriving combination of aesthetics which has not only challenged the frontiers between canonical texts and other forms previously considered subgenres by the Western canon, but which has also probed into new zones of textual liminality. For example, the culinary memoirs of female writers of Caribbean or African origin have cooked up many a new recipe for fiction.

Another point worth mentioning is the theoretical potential that the liminality inscribed in the term "crossings" implies, in the sense that its dynamics posits an ontological in-betweenness which is not contextual and transient but permanent. The potential of the double perspective, or as a matter of fact of the multiple perspectives which the

1. In recent years, writers have increasingly addressed the predicament of what used to be regarded as an impossible return to the mother country. Writers like Kiran Desai in The Inheritance of Loss or Abdulrazak Gurnah in Admiring Silence, for example, have not only taken their protagonists back to the motherland, but have also prompted ethical reflections about the politics of the diasporic text through a focus on the forced amnesia of the diasporic subject and the latent bond which continues to tie the migrant to the home country. 
term "crossings" suggests is probably best exemplified by Paul Gilroy's notion of the black Atlantic. In The Black Atlantic, Gilroy sketches a dynamic picture of Black Modernity in motion, and by doing so he posits the possibility of a paradigm which resists localization and allows for successive reterritorializations by dint of the fact that it operates on the basis of dynamic intersections.

In hindsight, the tradition of crossings, which has been characteristic and to a certain degree constitutive of the field of postcolonial studies has also contributed to making this area of critical analysis an exceptionally useful laboratory in which critical crossings of established narratives and subaltern worldviews have taken place. And to some extent the nature of the field and its specific queries have invited scholars to explore new arenas of critical investigation. For example, most historians would agree that schools like New Historicism have largely benefited from the findings of historians who have concentrated on the colonial and the postcolonial fields. Mary-Louise Pratt's seminal text Imperial Eyes: Travel Writing and Transculturation (1992) in particular has constituted a real breakthrough in problematizing one of the key postulates of epistemology, namely the presumed neutrality of scientific discourse. Indeed, when studying how the notion of the neutrality of scientific discourse has become acknowledged on a global scale, Pratt shows that this intellectual hegemony has gone hand in hand with the development of zones of influence in the colonial era and has been made possible thanks to the collusion between several parameters, the development of the merchant navy and overseas trade as well as the rise of the bourgeoisie and the development of the modern sciences. Her research into the conditions of production of scientific discourse at a time when scientists were dependent on captains to accept them on board their vessels to go on long journeys of exploration, forces us to reconsider and call into question the myth of the neutrality of scientific discourse. It also invites us to reflect on the disconnectedness of this discourse from economic or political concerns.

There is therefore more to the methodology of the postcolonial field than meets the eye, as the crossings are not merely thematic or formal, but have served as home to a tradition of trans-disciplinary undertakings which do not pick and mix within the methodology of the various disciplines of the humanities, but which cross over into adjacent fields when their specific methodology proves more relevant than the established one. In this respect the methodology of postcolonial studies responds to a call for contiguity which sociologist Emmanuel Renault explains when arguing for the need, within the humanities, to probe into the liminal areas beyond the zones of competence of one's own discipline. Drawing on the example of the concept of "social suffering," Renault shows that there is a point beyond which sociology cannot go, and where psychology should take over. It is also this type of disciplinary crossing which the concept ultimately allows and even suggests.

Despite the fact that the term "crossings" has retained its original relevance insofar as postcolonial cultural productions are concerned, the nature of the crossings, in particular in contemporary texts, needs to be redefined. The incomplete crossings as well as the imperfect trajectories which characterize cross-cultural encounters and exchanges at the turn of the twenty-first century, in a world which has not become more transparent thanks to information technologies and new means of transport, but has arguably become if not more opaque, at least differently so, invites us to reassess the notion of "crossings" as well as its pertinence. "Crossings" therefore continues to be an insightful 
entry point into the field of postcolonial studies, but beyond it, into the sister domains which have appeared in the wake of decolonization and the development of diasporization within the former colonial world, not only between the former colonies and the motherland, but also between former colonies themselves, as is the case with double diasporas.

This volume of Commonwealth Essays and Studies brings together texts on various aspects of the disciplinary crossings within the field of diaspora studies. Some of them work in the vein of literary genealogies, tracing the origins of the texts under study to a literary tradition, such as Corinne Bigot's or André Dodeman's articles. Others, like Kathie Birat's article on Caryl Phillips, Mathilde Rogez's or Fiona McCann's articles investigate the possibility of effective crossings in the polis, in the form of the actual sense of belonging that diasporic people can have. Other articles, like Sneharika Roy's and Laura Singeot's explore the theoretical potential of crossings in a more epistemological perspective, while Anne-Sophie Letessier concentrates on the limitations of certain media.

The first article of the volume concentrates on liminal spaces in the work of Steven Carroll. Xavier Pons repositions the motif of the threshold and its many adjacent figures in the larger context of Australian literature, where liminality and in-betweenness have always been centre stage, from the chronicles of the first years of the Australian settlement to contemporary reworkings of the motif in modern chronicles of suburbia as a locus of liminality. Xavier Pons focuses on both the temporal and topographical conceptions of liminality. This allows him to explore a very broad spectrum of interconnected themes, including the place between two ages or between life and death, and more importantly even, it allows him to envisage in-betweenness not so much as between two states or two conditions but more as having a foot in each.

In her analysis of Alice Munro's short story "The view from Castle Rock," Corinne Bigot shows how the seminal narrative of the journey to the New World resonates on a very personal level for Munro, as the short story is largely inspired by the transatlantic crossing that her ancestors undertook when they left Scotland for Canada. This seminal crossing, which is revisited by Munro in a fictional mode, largely revolves around the locus of the ship which, as Corinne Bigot reminds us, is the heterotopic locus par excellence. Drawing on Foucault but also on Deleuze and Guattari's notion of the line of flight (ligne de fuite) Corinne Bigot analyses the pivotal moments of the short story and the way the characters' epiphanies originate in the transatlantic crossing.

André Dodeman's study of Yann Martel's Life of Pi, "Crossing Oceans and Stories: Yann Martel's Life of Pi and the Survival Narrative," envisages another form of sea crossing, that of a survival narrative which draws on a rich tradition of precedents ranging from Robinson Crusoe to Lord of the Flies. The pair, constituted by the protagonist, Piscine Patel, and the tiger also stages the divide between man and animals and the spectre of the crossing of the line which in postcolonial fiction has often taken the form of the motif of reverting to type.

The volume then moves in the direction of an analysis of the motif of crossings in relation to the impermeability of certain lines. In her essay on performance in Caryl Phillips's novel Dancing in the Dark, Kathie Birat stresses the underlying tension that permeates the novel, as the form itself swiftly skates across various genres and textual formats (including newspaper articles and programs) while the protagonist experiences the constraints and radicality of the colour line and the centrality of the racial subtext 
for both blacks and whites. Focusing on the narrative choices as well as the zones of opacity characteristic of Phillips's writing and which critics have struggled to interpret, Kathie Birat convincingly evidences how the crossing of lines which is constitutive of artistic performance is problematized in the heavily charged context of the colour line in the first decades of the twentieth century in the United States.

Mathilde Rogez's article on Ivan Vladislavić's work, "Portrait of the Writer as a Flâneur, A Study of Ivan Vladislavić's Work" tackles similar issues of impermeability. Focusing on the intrinsic liminality of the figure of the flaneur, who not only traverses places but divests himself of the privilege of the ethnically "superior" by abandoning the car to travel on foot, Mathilde Rogez shows how Vladislavićs narrative allows for a repositioning of the observing eye which succeeds in becoming more fluid, and challenges the impermeability of boundaries. In a city where the social fractus has replaced the colour line, the flaneur evidences both the resilience of certain watertight lines and the opening up of certain aspects of life in Johannesburg.

In her comparative study of Robert McLiam Wilson's Ripley Bogle and Chikwava's Harare North, Fiona McCann focuses on the character's feelings of alienation, in cities like Belfast, Harare and London. Drawing on Jacques Rancière's concept of the "dissensus" as a mode of reflexion on political life, and stressing the contextual irony today of the term Commonwealth, when it has become obvious that the wealth is far from being commonly shared, Fiona McCann traces the mode of political being to which diasporas are often relegated. Her article expands on the modes of inscription into the politics of the city through a focus on that moment when diasporas emerge from invisibility and confusion to become visible and audible, or in Butlerian terms, when their lives cease to be precarious, not only socially but also politically.

In 'Shining in 'Paradoxical Splendor': The Staging of the 'difficult Relation' in Faulkner's Sagas as a Prefiguration of Postcolonial Epic," Sneharika Roy concentrates on the problematic crossings as well as on the zones of friction and opacity which too often slip out of focus in analyses of cross-cultural exchanges. Drawing on Glissant's concept of the relation in Poetics of Relation, Sneharika Roy discusses Glissant's paradoxical choice of Faulkner - often associated with the racialized history of the American South - as representative of a postcolonial epic. Looking closely at the specificities of the Faulknerian take on the epic genre, and in particular the way it departs from the teleological structure of seminal epics such as La Chanson de Roland or the Aenid, Roy provides a very convincing and stimulating reading of the paradoxes of both Glissant's Poetics of Relation and of Faulkner's work as a new epic.

In her essay on Australian writer Mudrooroo's novel The Undying (1998), Laura Singeot proposes to transpose Gilroy's concept of the "black Atlantic" to a "black Pacific." Her analysis seeks to reposition the Australian debate on Aboriginal identity in a broader context which takes into account the many influences and intersections which have had an impact on the shaping of Aboriginal identity in the second half of the twentieth century. This crossover from the Atlantic to the Pacific, which results in the shaping of a kaleidoscopic identity, is reflected in an aesthetics of generic mixing which Mudrooroo develops in The Undying and which still holds a unique position in Australian literature.

Lastly, in her essay on Jane Urquhart's Changing Heaven (1993), Anne Sophie Letessier concentrates on intermedial transpositions and on the specificities of the different me- 
dia, in particular text v. image, when it comes to making us see things and bringing the visible to visibility. Drawing on French philosopher and specialist of aesthetics DidiHubeman's distinction between the visible-legible-readable and the visual, and working on the pictorial intertext of Urquhart's novel, which combines references to Tintoretto and Velazquez, Anne-Sophie Letessier suggests that the novel implies that the gaze as a modality of the visual is always flawed.

Françoise KRAL

University of Caen Basse-Normandie

\section{Works Cited}

Desai, Kiran. The Inheritance of Loss. London: Penguin Books, 2006.

Gilroy, Paul. The Black. Atlantic. Modernity and Double Consciousness. Cambridge, MA: Harvard UP, 1993. GurnaH, Abdulrazak. Admiring Silence. London: Hamish Hamilton, 1996.

PRATT, Mary-Louise. Imperial Eyes: Travel Writing and Transculturation. London; New York: Routledge, 1992.

Renault, Emmanuel. Souffrances sociales. Philosophie, psychologie et politique. Paris: La Découverte, 2008. 